\title{
Comparison of N- and P/Q-Type Voltage-Gated Calcium Channel Current Inhibition
}

\author{
Kevin P. M. Currie and Aaron P. Fox \\ The Department of Pharmacological and Physiological Sciences, The University of Chicago, Chicago, Illinois 60637
}

Activation of $\mathrm{N}$ - and $\mathrm{P} / \mathrm{Q}$-type voltage-gated calcium channels triggers neurotransmitter release at central and peripheral synapses. These channels are targets for regulatory mechanisms, including inhibition by G-protein-linked receptors. Inhibition of P/Q-type channels has been less well studied than the extensively characterized inhibition of $\mathrm{N}$-type channels, but it is thought that they are inhibited by similar mechanisms although possibly to a lesser extent than $\mathrm{N}$-type channels. The aim of this study was to compare the inhibition of the two channel types.

Calcium currents were recorded from adrenal chromaffin cells and isolated by the selective blockers $\omega$-conotoxin GVIA ( 1 $\mu \mathrm{M})$ and $\omega$-agatoxin IVA (400 nM). The inhibition was elicited by ATP $(100 \mu \mathrm{M})$ or intracellular application of GTP- $\gamma$-S. It was classified as voltage-sensitive (relieved by a conditioning prepulse) or voltage-insensitive (present after a conditioning prepulse). The voltage-insensitive inhibition accounted for a $20 \%$ reduction of both currents, whereas the voltage-sensitive inhibition reduced the $\mathrm{N}$-type current by $45 \%$ but the P/Q-type current by $18 \%$. However, the voltage dependence of the inhibition, the time course of relief from inhibition during a conditioning prepulse, and the time course of reinhibition after such a prepulse showed few differences between the $\mathrm{N}$ - and $\mathrm{P} / \mathrm{Q}$-type channels. Assuming a simple bimolecular reaction, our data suggest that changes in the kinetics of the G-protein/ channel interaction alone cannot explain the differences in the inhibition of the $\mathrm{N}$ - and $\mathrm{P} / \mathrm{Q}$-type calcium channels. The subtle differences in inhibition may facilitate the selective regulation of neurotransmitter release.

Key words: calcium channel; G-protein; ATP; inhibition; patch clamp; GTP- $\gamma$-S; N-type calcium channel; $P / Q$-type calcium channel
Of the multiple subtypes of voltage-gated calcium channel current $\left(I_{\mathrm{Ca}}\right)$, it has been shown that calcium influx via the $\mathrm{N}-, \mathrm{P}$, and Q-subtypes triggers neurotransmission at central and peripheral synapses (Luebke et al., 1993; Takahashi and Momiyama, 1993; Regehr and Mintz, 1994; Wheeler et al., 1994; Waterman, 1996; Wright and Angus, 1996). N-type channels are identified pharmacologically as being blocked irreversibly by $\omega$-conotoxin GVIA ( $\omega$-Cgtx GVIA) (McCleskey et al., 1987; Plummer et al., 1989) and are encoded for by the class $\mathrm{B} \alpha_{1}$ subunit gene (Dubel et al., 1992; Williams et al., 1992). P-type channels are blocked potently by $\omega$-agatoxin IVA ( $\omega$-Aga IVA) (Mintz et al., 1992); Q-type channels also are blocked by $\omega$-Aga IVA but with a somewhat lower affinity (Zhang et al., 1993; Randall and Tsien, 1995). Biophysically, the P-type channels exhibit little or no inactivation during prolonged depolarizations, whereas Q-type channels show substantial inactivation even after $100 \mathrm{msec}$ (Llinás et al., 1989; Mintz et al., 1992; Randall and Tsien, 1995). It remains unclear which $\alpha$ subunit gene encodes for the P- and Q-type channels. The class A $\alpha_{1}$ subunit produced inactivating currents that more closely resembled the Q-type current (Zhang et al., 1993), but it also may encode for channels with properties similar to the P-type (Stea et al., 1994; Liu et al., 1996). Until these issues are resolved, many researchers in the field have adopted the terminology " $\mathrm{P} /$ Q-type" current when referring to either component.

Received Dec. 2, 1996; revised March 26, 1997; accepted March 31, 1997.

This work was supported by National Institutes of Health grants to A.P.F. We thank Dr. Zhong Zhou for kindly preparing the chromaffin cells and Dr. Nicholas Saccomano of Pfizer, Incorporated, Groton, CT, for the gift of $\omega$-Aga IVA.

Correspondence should be addressed to Dr. Kevin Currie, The Department of Pharmacological and Physiological Sciences, The University of Chicago, 947 East 58th Street, Chicago, IL 60637.

Copyright (C) 1997 Society for Neuroscience $0270-6474 / 97 / 174570-10 \$ 05.00 / 0$
Synaptic transmission can be regulated by neurotransmitter modulation of voltage-gated calcium channels, such as the well documented inhibition of N-type channels by activation of G-protein-linked receptors (Hille, 1992, 1994; Dolphin, 1995). Several pathways, most of which are membrane-delimited, converge on the $\mathrm{N}$-type channels. There is general consensus that this involves a direct effect of the activated G-protein subunit or subunits on the calcium channel itself, and recent evidence indicates a key role for the G-protein $\beta \gamma$ subunits (Herlitze et al., 1996; Ikeda, 1996). The inhibition exhibits characteristic gating shifts manifested as slowed activation kinetics, a diminution of the inhibition at positive membrane potentials, and partial relief from inhibition by conditioning prepulses (Bean, 1989; Elmslie et al., 1990; Penington et al., 1991). These effects have been incorporated into models in which the channels exhibit two functional gating states, one in the presence ("reluctant") and another in the absence ("willing") of inhibition (Bean, 1989; Elmslie et al., 1990; Boland and Bean, 1993; Golard and Siegelbaum, 1993).

Recently, it has become apparent that P/Q-type channels are inhibited by similar mechanisms (Mintz and Bean, 1993), but there has been little detailed comparison with N-type current inhibition. However, a few reports suggest that the N-type current is inhibited to a greater extent than the P/Q-type current (Mintz and Bean, 1993; Bayliss et al., 1995; Bourinet et al., 1996; Currie and Fox, 1996). Such differential targeting may have a role in the selective regulation of neurotransmission. Therefore, we have compared the similarities and differences in the inhibitory modulation of $\mathrm{N}$ - and P/Q-type $I_{\mathrm{Ca}}$ in bovine adrenal chromaffin cells.

\section{MATERIALS AND METHODS}

Culture of cells. Chromaffin cells were prepared by digestion of bovine adrenal glands with collagenase and purified by density gradient centrif- 
ugation, as previously described (Artalejo et al., 1992a). The cells were plated on collagen-coated glass coverslips $(22 \times 22 \mathrm{~mm})$ at a density of $\sim 0.15 \times 10^{6}$ cells $/ \mathrm{cm}^{2}$ and maintained in an incubator at $37^{\circ} \mathrm{C}$ in an atmosphere of $92.5 \%$ air $/ 7.5 \% \mathrm{CO}_{2}$ with a relative humidity of $90 \%$. Fibroblasts were suppressed effectively with cytosine arabinoside $(10 \mu \mathrm{M})$, leaving relatively pure chromaffin cell cultures. Although mixed, the cultures were enriched somewhat for epinephrine-containing over norepinephrine-containing cells. One-half of the incubation medium was exchanged every day. This medium consisted of DMEM/F12 (1:1) supplemented with fetal bovine serum (10\%), glutamine (2 mM), penicillin/ streptomycin $\left(100 \mathrm{U} \cdot \mathrm{ml}^{-1} / 100 \mu \mathrm{g} \cdot \mathrm{ml}^{-1}\right)$, cytosine arabinoside $(10 \mu \mathrm{M})$, and 5-fluorodeoxyuridine $(10 \mu \mathrm{M})$.

Electrophysiology. Chromaffin cells were voltage-clamped in the wholecell configuration of the patch-clamp technique (Hamill et al., 1981) with an Axopatch 1C amplifier (Axon Instruments, Foster City, CA) at a holding potential of $-80 \mathrm{mV}$, and $I_{\mathrm{Ca}}$ was activated by step depolarizations. Current-voltage curves were generated by voltage ramps of 100 msec duration from the holding potential $(-80 \mathrm{mV})$ to $+100 \mathrm{mV}$. Leak currents were generated by averaging 16 hyperpolarizing sweeps (steps or ramps). All of the data reported in this paper were capacitance- and leak-subtracted. The data were filtered at $2 \mathrm{kHz}$ and then digitized at 100 $\mu$ sec per point. Series resistance was compensated partially $(\approx 80 \%)$ by using the series resistance compensation circuit of the Axopatch-1C amplifier. Electrodes were pulled from microhematocrit capillary tubes (Drummond, Broomall, PA) and coated with SYLGARD (Dow Corning, Midland, MI). After fire polishing, final electrode resistances when filled with the CsCl-based patch pipette solution (see below) were $\sim 1.5-2.0$ $\mathrm{M} \Omega$. Voltage protocols and data analysis were performed in AxoBasic. Data are reported as mean \pm SEM, and statistical significance was determined with paired or independent Student's $t$ test.

Solutions. Electrodes were filled with (in mM): $\mathrm{CsCl} 110, \mathrm{MgCl}_{2} 4$, HEPES 20, EGTA 10, GTP 0.35, ATP 4, and creatine phosphate 14, $\mathrm{pH}$ 7.3 (adjusted by $\mathrm{CsOH}$ ); osmolality, $\approx 310 \mathrm{mOsm}$. In some experiments 0.07 GTP- $\gamma$-S replaced an equal amount of GTP. The NaCl-based extracellular recording medium contained (in $\mathrm{mM}$ ): $\mathrm{NaCl} 140, \mathrm{KCl} 2$, glucose 10, HEPES 10, $\mathrm{CaCl}_{2}$ 10, and tetrodotoxin (TTX) $2 \mu \mathrm{M}, \mathrm{pH} 7.3$ (adjusted with $\mathrm{NaOH}$ ); osmolality, $\approx 315 \mathrm{mOsm}$. In some experiments the $\mathrm{NaCl}$ was replaced by choline $\mathrm{Cl}$. Nisoldipine $(1 \mu \mathrm{M})$ was present in all extracellular solutions to block any facilitation (L-type) $I_{\mathrm{Ca}}$. ATP for extracellular application was prepared as a stock solution in distilled water and kept on ice before dilution to final concentrations in extracellular recording medium. $\omega$-Conotoxin GVIA (Alomone Labs, Jerusalem, Israel) and $\omega$-agatoxin IVA (gift from Dr. N. Saccomano, Pfizer, Groton, CT) were stored at $-20^{\circ} \mathrm{C}$ either lyophilized or as concentrated stocks in distilled water. Final concentrations were prepared daily by dilution in extracellular recording medium. Bovine serum albumin (BSA; $(1 \mathrm{mg} / \mathrm{ml})$ was included in the recording medium to prevent nonspecific binding of the peptides. BSA itself was found to have no effect on $I_{\mathrm{Ca}}$.

After the formation of a seal, the cell was perfused continually by an Adams \& List (Westbury, NY) DAD-12 superfusion system. In brief, this consisted of a "sewer pipe" arrangement in which a quartz capillary of 100 $\mu \mathrm{m}$ diameter is placed close to the cell. The sewer pipe was connected to six reservoirs, and flow from these was controlled by valves operated by the AxoBasic software. This enabled the cell to be perfused continually with fresh solution and the rapid exchange of solutions for application of toxins or ATP. The exchange time for switching between two solutions was $<1 \mathrm{sec}$. The bath volume was kept relatively constant by using an outlet connected to a vacuum. All solutions perfused in this way contained $1 \mathrm{mg} / \mathrm{ml} \mathrm{BSA}$. All experiments were performed at room temperature $\left(\sim 23^{\circ} \mathrm{C}\right)$.

\section{RESULTS}

We have shown previously that ATP inhibits both N-type and $\mathrm{P} / \mathrm{Q}$-type calcium currents in adrenal chromaffin cells. The aims of this study were to investigate the similarities and differences in the inhibitory response of the $\mathrm{N}$ - and P/Q-type calcium currents. These experiments included prepulse depolarizations to very positive potentials. Chromaffin cells possess L-type calcium channels, which are normally quiescent but can be recruited by similar depolarizing prepulses, neurotransmitters such as dopamine that elevate cAMP, or rapid repetitive depolarizations in the physiological range (Fenwick et al., 1982; Artalejo et al., 1990, 1992b). To avoid the complication of recruitment of these channels, we
A

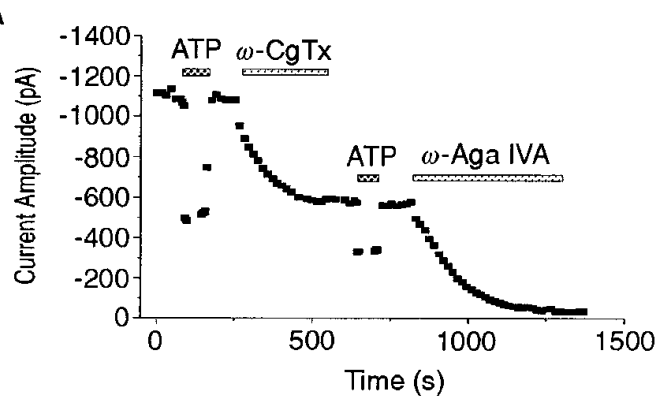

B

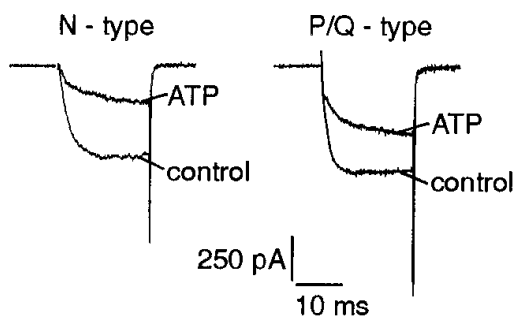

C
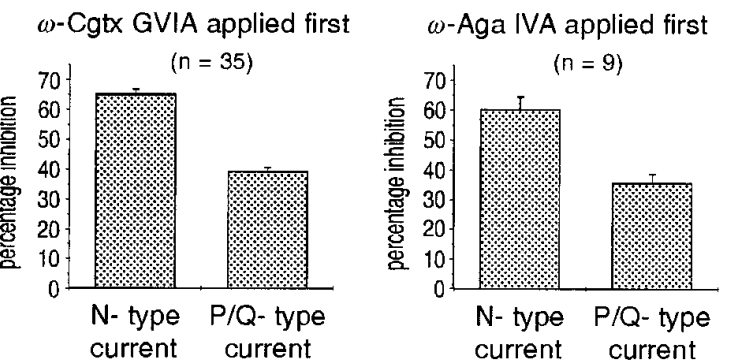

Figure 1. ATP inhibits N-type $I_{\mathrm{Ca}}$ to a greater extent than P/Q-type $I_{\mathrm{Ca}}$. $A$, Plotted is peak current amplitude against time. Cells were depolarized to $+20 \mathrm{mV}$ from a holding potential of $-80 \mathrm{mV}$. ATP $(100 \mu \mathrm{M})$ and toxins were applied to the cell, as indicated by the horizontal bars. The combination of $\omega$-Cgtx GVIA $(1 \mu \mathrm{M})$ and $\omega$-Aga IVA (400 nM) blocked almost all of the current in this cell. ATP inhibited both the $\omega$-Cgtx GVIA and $\omega$-Aga IVA-sensitive current components. $B, N$-type and $P / Q$-type $I_{\mathrm{Ca}}$ in the presence and absence (control) of $A T P$. The $N$-type $I_{\mathrm{Ca}}$ currents are generated by subtracting the currents obtained after $\omega$-Cgtx GVIA from those obtained before $\omega$-Cgtx GVIA. The $P / Q$-type currents are that component of $I_{\mathrm{Ca}}$ that remained after block with $\omega$-Cgtx GVIA. Note the slowed activation kinetics and the larger inhibition of the $N$-type current. $C$, The bar chart on the left plots the percentage of inhibition produced by $100 \mu \mathrm{M}$ ATP in 35 cells like the one shown above $(A, B)$. The percentage of inhibition of peak inward current amplitude is plotted for both the $\mathrm{N}$ and $\mathrm{P} / \mathrm{Q}$-type currents. The currents were isolated by obtaining data before and after application of $\omega$-Cgtx GVIA. There was a significantly larger inhibition of N-type, as compared with $\mathrm{P} / \mathrm{Q}$-type, current. The bar chart on the right plots data collected from nine cells in which ATP was applied before and after $\omega$-Aga IVA. In this case the current after block with $\omega$-Aga IVA was termed the N-type $I_{\mathrm{Ca}}$, and the difference currents were $\mathrm{P} / \mathrm{Q}$-type $I_{\mathrm{Ca}}$.

included $1 \mu \mathrm{M}$ nisoldipine, which selectively blocks these L-type channels (Artalejo et al., 1991) in all extracellular solutions.

In the presence of nisoldipine $(1 \mu \mathrm{M})$ the $I_{\mathrm{Ca}}$ was composed almost totally of N-type and P/Q-type $I_{\mathrm{Ca}}$. Perfusion of $1 \mu \mathrm{M}$ $\omega$-Cgtx GVIA to block the N-type current reduced the peak inward $I_{\mathrm{Ca}}$ amplitude by $48 \pm 2 \%(n=20)$. Subsequent perfusion of $400 \mathrm{~nm} \omega$-Aga IVA to identify the P/Q-type $I_{\mathrm{Ca}}$ blocked most of the remaining current, equivalent to $45 \pm 2 \%(n=17)$ of the total current amplitude (Fig. 1A). A small component of the total 
A

Figure 2. The magnitude of the voltagesensitive block is different for the $\mathrm{N}$ - and $\mathrm{P} / \mathrm{Q}$-type currents. $A$, Shown are current records of $\mathrm{N}$-type and $\mathrm{P} / \mathrm{Q}$-type $I_{\mathrm{Ca}}$ isolated as in Figure 1. The traces labeled control were obtained in the absence of ATP, the traces labeled ATP were obtained in the presence of $100 \mu \mathrm{M}$ ATP, and the traces labeled $A T P+$ prepulse were obtained in the continued presence of ATP but preceded by a depolarizing prepulse to +100 $\mathrm{mV}$ lasting $50 \mathrm{msec}$. The voltage protocol is illustrated above the current records. The prepulse relieved $\sim 70 \%$ of the $\mathrm{N}$-type current inhibition but only $\sim 50 \%$ of the P/Qtype current inhibition. $B$, The bar chart on the left plots the percentage of inhibition produced by $100 \mu \mathrm{M}$ ATP for 17 cells like that in $A$. The inhibition is divided into the voltage-sensitive component (relieved by depolarizing prepulses) and the voltageinsensitive component (the inhibition that persists after a prepulse). The voltageinsensitive component was similar for the two currents, but the voltage-sensitive component was more than twice as large in the $\mathrm{N}$-type current as in the P/Q-type current. The bar chart on the right illustrates that the same pattern of inhibition was seen if $\omega$-Aga IVA (rather than $\omega$-Cgtx GVIA) was used to isolate the currents. This single prepulse did not produce significant reversal of $\omega$-Aga IVA block.

B

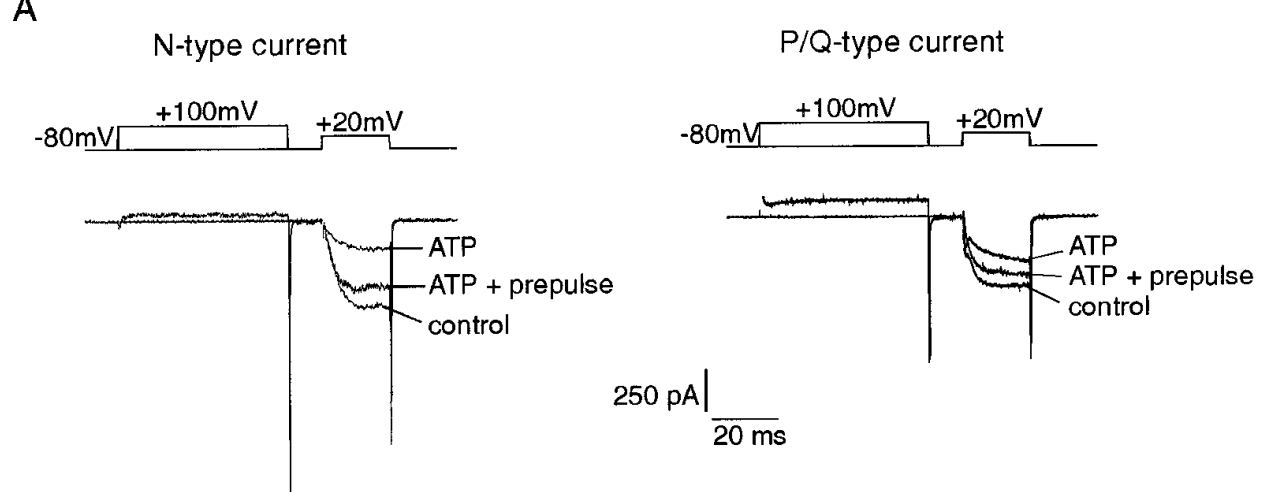

$\omega$-conotoxin GVIA applied first
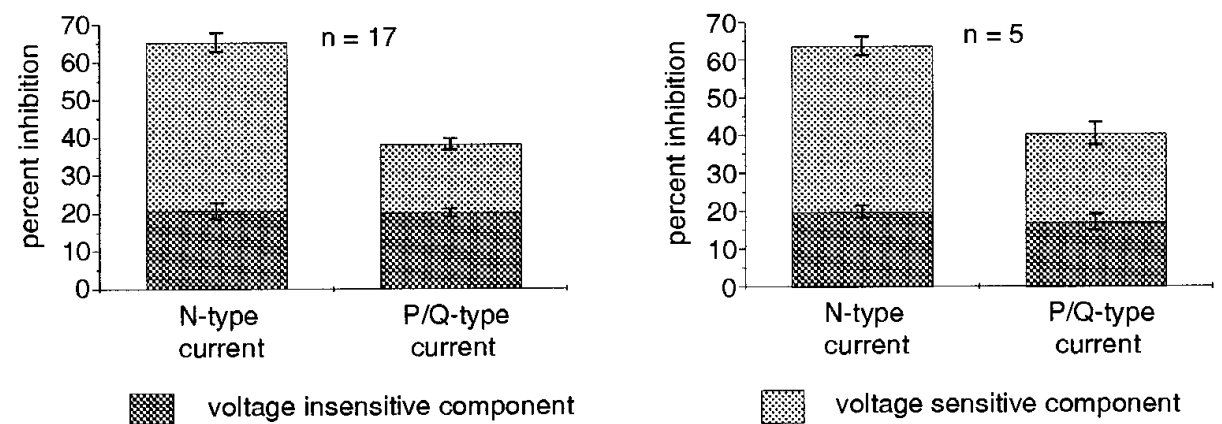

current $(7 \pm 1 \% ; n=17)$ remained after application of both toxins. There was no difference in the percentage block by the two toxins if the order of application was reversed (i.e., $\omega$-Aga IVA applied before $\omega$-Cgtx GVIA), indicating that there was no overlap in the pool of channels blocked by each toxin. In this case $\omega$-Aga IVA blocked $43 \pm 3 \%$ and $\omega$-Cgtx GVIA blocked $47 \pm 3 \%$ of the peak $I_{\mathrm{Ca}}(n=9)$. Some cells bathed in the NaCl-based recording solution exhibited a small TTX-resistant inward sodium current. This current decayed rapidly $(3-4 \mathrm{msec})$ during the depolarizing steps used to activate $I_{\mathrm{Ca}}$ and was fully inactivated either by depolarizing prepulses or by changing the holding potential to $-50 \mathrm{mV}$. The current also disappeared when the cells were perfused with choline Cl-based recording solution. It did not interfere with the measurement of peak $I_{\mathrm{Ca}}$, because changing the recording solution from $\mathrm{NaCl}$ to choline $\mathrm{Cl}$-based solution had no effect on the measured peak inward $I_{\mathrm{Ca}}$ amplitude.

\section{ATP inhibits $N$-type $I_{\mathrm{Ca}}$ to a greater extent than P/Q-type $I_{\text {Ca }}$}

To compare the inhibition of the N- and P/Q-type currents, we applied a supramaximal dose of ATP $(100 \mu \mathrm{M})$ to cells before and after application of $\omega$-Cgtx GVIA (Fig. $1 A$ ). The $I_{\mathrm{Ca}}$ that remained after application of $\omega$-Cgtx GVIA was termed the P/Qtype $I_{\mathrm{Ca}}$. Subtraction of the currents obtained after $\omega$-Cgtx GVIA application from those obtained before $\omega$-Cgtx GVIA application yielded a difference current that was pure $\mathrm{N}$-type $I_{\mathrm{Ca}}$. Figure $1 B$ shows that the $\mathrm{N}$-type $I_{\mathrm{Ca}}$ was inhibited to a greater extent than the P/Q-type $I_{\mathrm{Ca}}$ and that the activation kinetics of both currents were slowed. After very long steps there was often little or no inhibition, because it was slowly relieved during the depolarization. Thus all current amplitudes from the same cell were measured at a fixed time after activation of the current (typically $\sim 10$ msec) corresponding to the peak of the control $I_{\mathrm{Ca}}$. Although arbitrary, it is common practice to measure the inhibition in this manner. Activation of N-type channels in chromaffin cells is slightly slower than that of P/Q-type channels (Artalejo et al., 1992a), but we were careful to measure the amplitudes at a point at which both currents had peaked.

The mean percentage of inhibition by ATP was $65 \pm 1.6 \%$ for the N-type current and $39 \pm 1.2 \%(n=35 ; p<0.001)$ for the $\mathrm{P} / \mathrm{Q}$-type current. The same pattern of differential inhibition was seen if the order of toxin application was reversed so that ATP was applied before and after application of $\omega$-Aga IVA (Fig. 1C). In this case the current remaining after block with $\omega$-Aga IVA was the N-type $I_{\mathrm{Ca}}$, and the $\mathrm{P} / \mathrm{Q}$-type $I_{\mathrm{Ca}}$ was the subtracted difference current. In nine cells recorded in this way the N-type current was inhibited by $60 \pm 4.3 \%$, and the P/Q-type current inhibition was $36 \pm 3.0 \%(p<0.001)$.

\section{Differences in the voltage sensitivity of the inhibition of $\mathrm{N}$ - and P/Q-type currents}

The ATP-mediated inhibition of $I_{\mathrm{Ca}}$ exhibited voltage sensitivity; it was diminished at very positive test potentials and was relieved in part by depolarizing prepulses to very positive potentials (Currie and Fox, 1996). The two current components were isolated in the same manner as shown in Figure 1 to determine whether the inhibition of the $\mathrm{N}$ - and $\mathrm{P} / \mathrm{Q}$-type $I_{\mathrm{Ca}}$ was equally voltagesensitive. Depolarizing voltage step commands to $+20 \mathrm{mV}$ for 20 msec were used to activate the currents in control conditions and with ATP present to elicit the inhibition. Then, still in the presence of ATP, $I_{\mathrm{Ca}}$ was activated again, but the test pulse was preceded by a depolarizing prepulse to $+100 \mathrm{mV}$ for $50 \mathrm{msec}$ (Fig. $2 A$ ). Such prepulses relieved a significantly greater proportion of the N-type current inhibition $(69 \pm 3 \%)$ than the P/Q-type cur- 
rent inhibition $(47 \pm 3 \% ; n=17 ; p<0.001)$. Note that, in control conditions in the absence of inhibition, identical prepulses had no effect on $I_{\mathrm{Ca}}$, because in chromaffin cells these channels show no voltage-dependent inactivation (Artalejo et al., 1992a). Thus under control conditions the peak amplitude of those currents preceded by a prepulse was $98.4 \pm 0.4 \%(n=23)$ of those not preceded by a prepulse.

Figure $2 B$ shows the pooled data for these experiments in which the total percentage of inhibition of the peak current is subdivided into the voltage-sensitive component (the component that was relieved by a depolarizing prepulse) and the voltage-insensitive component (the component of the inhibition that was not relieved by a depolarizing prepulse). The voltage-insensitive component accounted for approximately the same amount of inhibition for both currents. In contrast, approximately twice as much $\mathrm{N}$-type current inhibition was voltage-sensitive as compared with the $\mathrm{P} / \mathrm{Q}$-type current. The same pattern of inhibition was seen if the data were obtained before and after $\omega$-Aga IVA rather than $\omega$-Cgtx GVIA to isolate the currents (Fig. $2 B$ ). It should be noted that in using this protocol there will be some reblock of the voltage-sensitive inhibition during the $10 \mathrm{msec}$ interval between the prepulse and test pulse (see below). However, this is likely to be $<10 \%$ and to be similar for the two current types.

\section{Intracellular GTP- $\gamma$-S mimics the differential inhibition produced by ATP}

GTP- $\gamma-\mathrm{S}$ is an analog of GTP that is resistant to hydrolysis, and therefore irreversibly activates G-proteins. By including GTP- $\gamma-S$ in the patch pipette solution, the inhibition of $I_{\mathrm{Ca}}$ could be elicited without the need for receptor activation by ATP. In all experiments reported here, after inhibition of $I_{\mathrm{Ca}}$ by the GTP- $\gamma$-S, ATP was applied to the cells to ensure that the G-proteins were fully activated and that the inhibition was maximal. In most cases the response to ATP was occluded, although in some cells it did produce a small increase in the inhibition.

The GTP- $\gamma$-S-containing patch pipette solution was identical to the normal solution except that $70 \mu \mathrm{M}$ (one-fifth) of the GTP was replaced by GTP- $\gamma-\mathrm{S}$. Once the whole-cell configuration was obtained, the GTP- $\gamma$-S slowly dialyzed into the cell and activated the G-proteins, causing an inhibition of the calcium current over a period of 5-7 min (Fig. 3A). In many cells the GTP- $\gamma-\mathrm{S}$ appeared to activate transiently an inward current over the same time course (data not shown). This inward current decayed back to baseline within a few minutes in almost all cells, and those cells in which this was not the case were discarded. The ionic nature of this current was not investigated in this study. Figure $3 A$ shows that the inhibition of $I_{\mathrm{Ca}}$ produced by GTP- $\gamma-\mathrm{S}$ was similar to that produced by ATP. The currents on the left were recorded shortly after breaking into the cell before the GTP- $\gamma$-S had time to diffuse into the cell and activate the G-proteins. A prepulse given at this time had no effect on the amplitude or kinetics of $I_{\mathrm{Ca}}$. The currents on the right were recorded 7-8 min later after the GTP- $\gamma$-S had inhibited the current. A prepulse given at this time sped the activation kinetics and increased the amplitude of $I_{\mathrm{Ca}}$ due to relief of the voltage-sensitive component of the inhibition.

When GTP- $\gamma$-S was used to produce the inhibition, the differential targeting of the $\mathrm{N}$ - and P/Q-type $I_{\mathrm{Ca}}$ was still apparent. This was manifested in the percentage of current blocked by $\omega$-Cgtx GVIA (Fig. 3B). In cells loaded with GTP- $\gamma$-S-containing patch pipette solution, $\omega$-Cgtx GVIA blocked $25 \pm 1.8 \%(n=27)$ of the current, and in cells loaded with control patch pipette solution containing no GTP- $\gamma$-S, it blocked $48 \pm 2.4 \%\left(n=20 ; p<10^{-9}\right)$.
A GTP- $\gamma$-S patch pipette solution

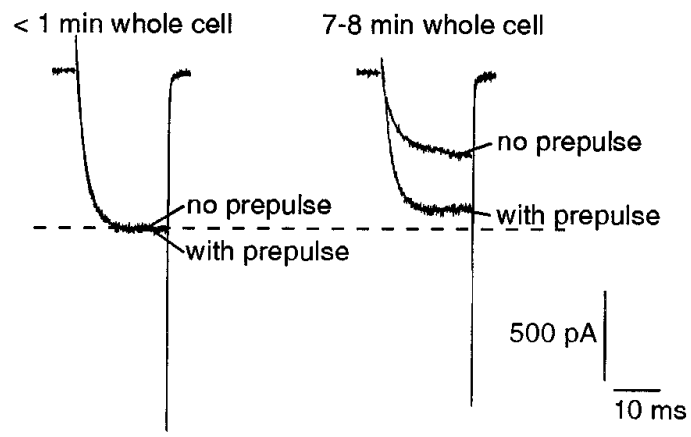

B Percentage of current blocked by $\omega$-Cgtx GVIA

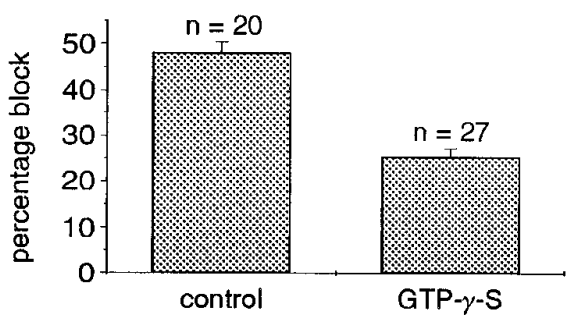

C

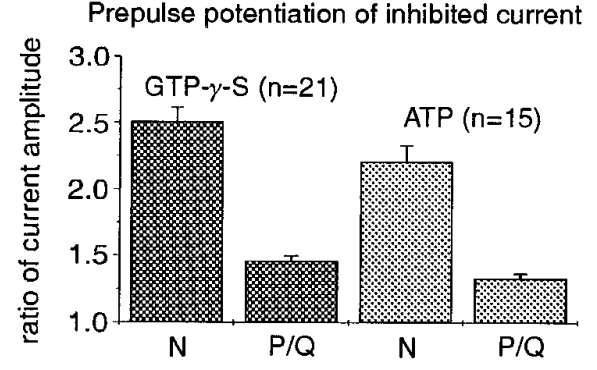

Figure 3. Intracellular GTP- $\gamma$-S mimics the inhibition elicited by ATP. $A$, Currents recorded from a cell with patch pipette solution containing GTP- $\gamma$-S. For these experiments one-fifth of the GTP in the patch pipette solution (total GTP $=350 \mu \mathrm{M}$ ) was replaced with an equal amount (70 $\mu \mathrm{M})$ of GTP- $\gamma$-S. The currents on the left were recorded within 1 min of entering the whole-cell configuration before significant activation of G-proteins by the GTP- $\gamma$-S. Those on the right were recorded 7-8 min after entering the whole-cell configuration. Each trace shows two superimposed currents. The control current was elicited by a $20 \mathrm{msec}$ test pulse to $+20 \mathrm{mV}$ with no prepulse (labeled no prepulse). The second current was preceded by a depolarizing prepulse to $+100 \mathrm{mV}$ for $50 \mathrm{msec}, 10 \mathrm{msec}$ before the test pulse (labeled with prepulse). GTP- $\gamma$-S inhibits $I_{\mathrm{Ca}}$ and slows the activation kinetics of $I_{\mathrm{Ca}}$ in a manner indistinguishable from ATP. The dashed line is for illustrative purposes and represents the peak amplitude of the uninhibited current. $B$, Plotted is the percentage block of $I_{\mathrm{Ca}}$ produced by $1 \mu \mathrm{M} \omega$-Cgtx GVIA for cells loaded with control or GTP- $\gamma$-S containing patch pipette solution. There was a significant reduction in toxin block when GTP- $\gamma$-S was present in the patch pipette solution. $C$, Shown is the potentiation of $\mathrm{N}$ - and $\mathrm{P} / \mathrm{Q}$-type $I_{\mathrm{Ca}}$ amplitude produced by prepulses on $G T P-\gamma-S$ (as shown in $A$ ) or $A T P(100 \mu \mathrm{M})$ inhibited currents. The increase in current amplitude produced by the prepulses was attributable to relief of the voltage-sensitive component of the inhibition. It is presented as the ratio of the current amplitude with a prepulse relative to that without a prepulse. The N-type current was potentiated significantly more than the $\mathrm{P} / \mathrm{Q}$-type current, reflecting the differential voltage sensitivity of the inhibition for the two channel types.

This is consistent with a higher proportion of the N-type current being inhibited by the GTP- $\gamma-\mathrm{S}$, as compared with the P/Q-type current.

The voltage-sensitive component of the inhibition produced by 


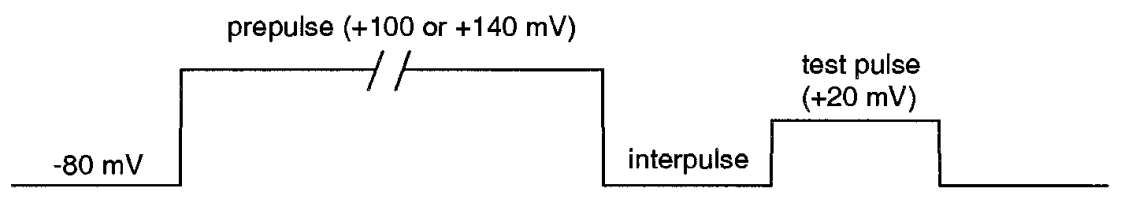

A

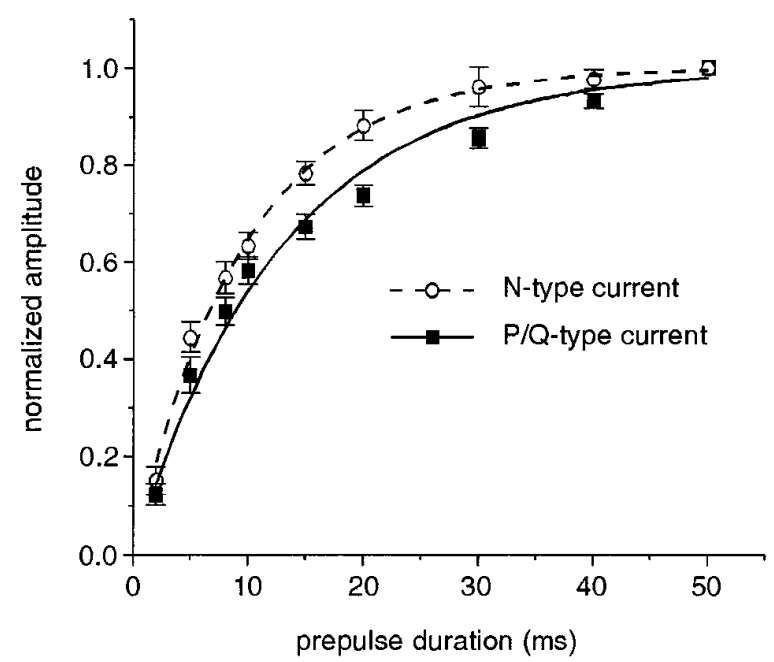

B

Prepulses to $+140 \mathrm{mV}$ $(n=5)$

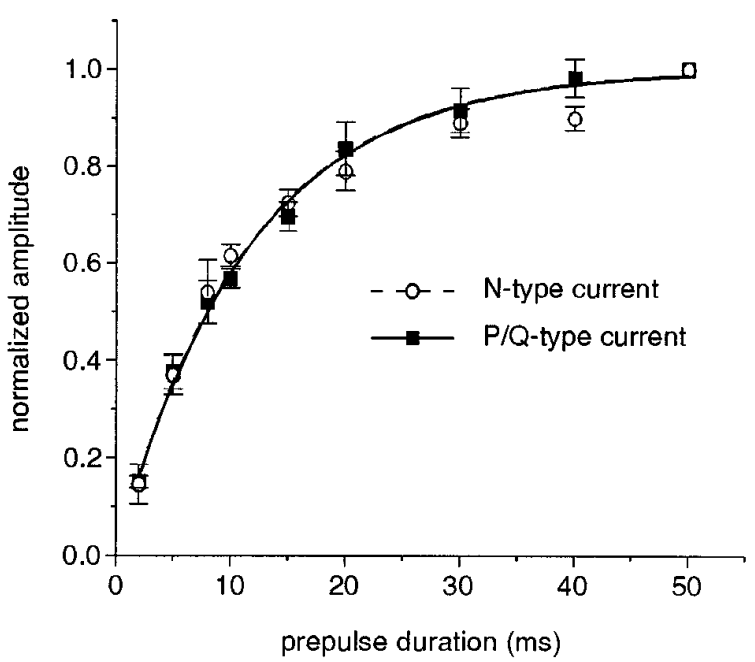

Figure 4. Time course of relief from inhibition is similar for N- and P/Q-type currents. The voltage protocol used is shown at the top. The holding potential was $-80 \mathrm{mV}$, and the test pulse was of $20 \mathrm{msec}$ duration to $+20 \mathrm{mV}$. The test pulse was preceded by a prepulse (to either +100 or $+140 \mathrm{mV}$ ), and the two were separated by an interpulse of $10 \mathrm{msec}$ during which the cell was returned to the holding potential. The patch pipette solution contained GTP- $\gamma-\mathrm{S}(70 \mu \mathrm{M})$ to elicit inhibition. The voltage protocols were repeated before and after application of $\omega$-Cgtx GVIA (1 $\mu \mathrm{M})$ to isolate the N- and P/Q type currents. $A$, Plotted is relief from inhibition as a function of prepulse duration by prepulses to $+100 \mathrm{mV}$. The increase in current amplitude produced by each of the prepulses (i.e., the amplitude of the current with a prepulse minus the amplitude of a current without a prepulse) was normalized to that produced by the longest duration prepulse $(50 \mathrm{msec})$, which is known to produce a maximal relief from inhibition. The data were fit with a single exponential, giving time constants of $9.8 \pm 0.7 \mathrm{msec}$ for the $N$-type current and $13.1 \pm 1.0 \mathrm{msec}$ for the $P / Q$-type current. $B$, Plotted is relief from inhibition by prepulses to $+140 \mathrm{mV}$. Time constants were $11.5 \pm 1.0 \mathrm{msec}$ for $N$-type current and $11.7 \pm 0.8 \mathrm{msec}$ for $P / Q$-type current.

GTP- $\gamma$-S was investigated by using a prepulse protocol like that shown in Figure $2 A$. The $\mathrm{N}$ - and $\mathrm{P} / \mathrm{Q}$-type $I_{\mathrm{Ca}}$ were isolated by using $\omega$-Cgtx GVIA as before. Because dialysis of GTP- $\gamma$-S into the cell starts immediately on entering the whole-cell configuration, there was no way to obtain reliable control (uninhibited) data. Thus, the amount of voltage-sensitive inhibition was quantified by determining the increase in current amplitude produced by a prepulse relative to the amplitude of the current remaining after full inhibition (Fig. $3 A$ ). This potentiation of current amplitude was $2.51 \pm 0.11$ for the N-type $I_{\mathrm{Ca}}$ and $1.46 \pm 0.04(n=21$; $p<10^{-9}$ ) for the $\mathrm{P} / \mathrm{Q}$-type $I_{\mathrm{Ca}}$, illustrating the greater degree of voltage-sensitive inhibition of the $\mathrm{N}$-type current relative to the $\mathrm{P} / \mathrm{Q}$-type current. The same analysis performed on currents inhibited by ATP application produced similar results (Fig. 3C). The potentiation was $2.20 \pm 0.12$ for the N-type current and $1.33 \pm 0.03\left(n=15 ; p<10^{-4}\right)$ for the $\mathrm{P} / \mathrm{Q}$-type current.

\section{Comparison of the voltage-sensitive inhibition}

Because the voltage-sensitive component of the inhibition accounted for the differential targeting of the two current types, it was investigated more closely by varying the parameters of the prepulse protocol. The voltage protocols were repeated before and after application of $\omega$-Cgtx GVIA to isolate the $\mathrm{N}$ - and $\mathrm{P} / \mathrm{Q}$-type $I_{\mathrm{Ca}}$. GTP- $\gamma$-S patch pipette solution was used to stimu- late the inhibition to minimize any complications with desensitization of the agonist response, but experiments also were done using ATP to stimulate the inhibition. Any cells that showed excessive desensitization or rundown over the course of the protocol were discarded.

Figure 4 shows the data in which the time course of relief from inhibition was investigated. Prepulses were to either +100 or $+140 \mathrm{mV}$ and were separated from the test pulse by an interval of $10 \mathrm{msec}$. The duration of the prepulse was varied from 2 to 50 msec. The current increase caused by each prepulse (over currents activated with no prepulse preceding them) was normalized, and the data were fit with a single exponential to determine the time constant for the relief from inhibition. At $+100 \mathrm{mV}$ (Fig. $4 A$ ) the time constant for the $\mathrm{N}$-type current was $9.8 \pm 0.7 \mathrm{msec}(n=12)$, and for the $\mathrm{P} / \mathrm{Q}$-type current there was a small but significant increase in the time constant to $13.1 \pm 1.0 \mathrm{msec}(n=12 ; p=$ $0.01)$. When this was repeated using ATP to produce the inhibition, there was a small difference in the time constants, but it was not statistically significant (N-type $=9.9 \pm 1.0 \mathrm{msec}$ and P/Qtype $=10.8 \pm 1.8 \mathrm{msec} ; n=4)$. At $+140 \mathrm{mV}$ (Fig. $4 B$ ) there was no difference in the time course for relief from inhibition with time constants of $11.5 \pm 1.0$ and $11.7 \pm 0.8 \mathrm{msec}(n=5)$ for the $\mathrm{N}$ - and P/Q-type currents, respectively. 


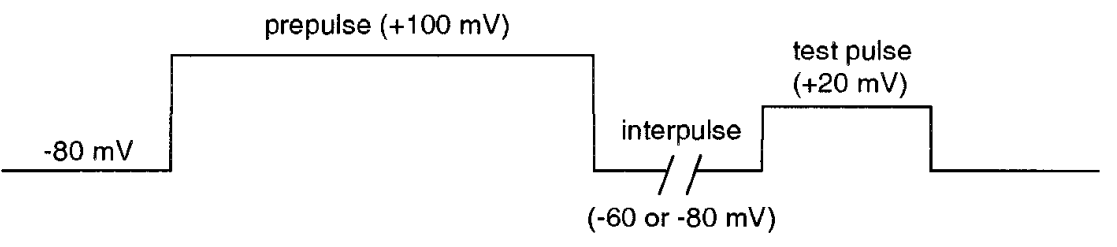

A

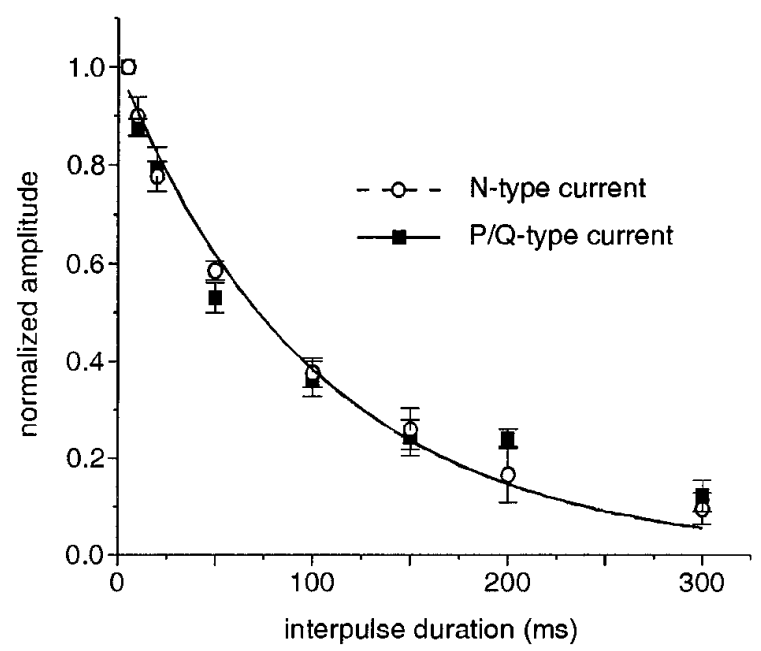

B reinhibition at $-80 \mathrm{mV}(\mathrm{n}=7)$

Figure 5. Time course of reinhibition is similar for $\mathrm{N}$ - and $\mathrm{P} / \mathrm{Q}$-type currents. The voltage protocol used is shown at the top. The holding potential was $-80 \mathrm{mV}$, and the test pulse was of $20 \mathrm{msec}$ duration to $+20 \mathrm{mV}$. The test pulse was preceded by a prepulse of $50 \mathrm{msec}$ duration to $+100 \mathrm{mV}$, and the two were separated by an interpulse during which the cell was repolarized to either $-60 \mathrm{mV}$ or $-80 \mathrm{mV}$. The duration of the interpulse was varied from 5 to $300 \mathrm{msec}$. The patch pipette solution contained GTP- $\gamma-\mathrm{S}(70 \mu \mathrm{M})$ to elicit inhibition. The voltage protocols were repeated before and after application of $\omega$-Cgtx GVIA (1 $\mu \mathrm{M})$ to isolate the $\mathrm{N}$ - and $\mathrm{P} / \mathrm{Q}$ type currents. $A$, Plotted is reinhibition as a function of interpulse duration at $-60 \mathrm{mV}$. The increase in current amplitude caused by each of the prepulses was normalized to that produced by a prepulse followed by the shortest duration of interpulse $(5 \mathrm{msec})$. The data were fit with a single exponential, giving time constants of reinhibition of $108 \pm 11 \mathrm{msec}$ for the $N$-type and $105 \pm 11 \mathrm{msec}$ for the $P / Q$-type currents. $B$, Plotted is reinhibition at -80 $\mathrm{mV}$. The time constants of the reinhibition were $112 \pm 17 \mathrm{msec}$ for the $N$-type current and $91 \pm 8 \mathrm{msec}$ for the $P / Q$-type current.

Figure 5 explores the time course for channel reinhibition after a prepulse to $+100 \mathrm{mV}$. When the cell is repolarized after the prepulse, the channels become reinhibited, so by varying the duration of the interpulse between the prepulse and test pulse, the time course of this reinhibition was determined. This was repeated at potentials of $-60,-80$, and $-100 \mathrm{mV}$. The prepulse was to $+100 \mathrm{mV}$ for $50 \mathrm{msec}$ and the interpulse duration was varied from 5 to $300 \mathrm{msec}$. The increase in current produced by the prepulses was normalized, and the data were fit with a single exponential decay. Figure $5 A$ shows that at $-60 \mathrm{mV}$ the time constants for reinhibition of the $\mathrm{N}$ - and $\mathrm{P} / \mathrm{Q}$-type currents were virtually identical at $108 \pm 11$ and $105 \pm 11$ msec, respectively $(n=5)$. At $-80 \mathrm{mV}$ the time constants again were not significantly different when the inhibition was elicited either by GTP- $\gamma$-S-containing patch pipette solution (Fig. 5B) (N-type = $112 \pm 17 \mathrm{msec} ; \mathrm{P} / \mathrm{Q}$-type $=91 \pm 8 \mathrm{msec} ; n=7)$ or by ATP application $(\mathrm{N}$-type $=110 \pm 7 \mathrm{msec} ; \mathrm{P} / \mathrm{Q}$-type $=87 \pm 10 \mathrm{msec} ; n=$ 5). Similarly, at $-100 \mathrm{mV}$ (data not shown) there was no statistically significant difference between the time constants of reinhibition for the N-type $(143 \pm 17 \mathrm{msec})$ and the P/Q-type currents $(125 \pm 11$ msec; $n=5$ ).

The voltage dependence of the relief from inhibition was studied by varying the potential to which the prepulse was stepped (Fig. 6). Prepulses to increasingly positive potentials relieve more of the inhibition, so for a prepulse of a fixed duration the voltage dependence of the relief can be compared for the two current types. The prepulse duration was $10 \mathrm{msec}$, as was the interpulse duration. Prepulse potential was changed in the range between $-10 \mathrm{mV}$ and $+120 \mathrm{mV}$. The increase in current amplitude for each prepulse was normalized, and the data were fit with a sigmoidal curve (Fig. 6). The midpoint of the curve (representing $50 \%$ of maximal relief from inhibition) was found to be shifted significantly in the hyperpolarized direction for the P/Q-type current $(+40 \pm 1.9 \mathrm{mV})$ relative to the $\mathrm{N}$-type current $(+51 \pm 1.8$ $\mathrm{mV} ; n=6 ; p<0.001)$. The slight change in the slope of the curve was not significant. Similar data were obtained using ATP to inhibit $I_{\mathrm{Ca}}$. The midpoint of inhibition was $+40 \pm 2 \mathrm{mV}$ for the $\mathrm{P} / \mathrm{Q}$-type current and $+56 \pm 2 \mathrm{mV}(n=6 ; p<0.001)$ for the $\mathrm{N}$-type current. The experiments were repeated with a prepulse duration of $100 \mathrm{msec}$ rather than $10 \mathrm{msec}$. The data were shifted slightly to the left for both current types, but there remained a significant difference between the two, with a midpoint for the $\mathrm{P} / \mathrm{Q}$-type current of $+31 \pm 2 \mathrm{mV}$ and for the N-type current of $+47 \pm 2 \mathrm{mV}(n=4 ; p=0.03)$.

\section{Comparison of the current-voltage relationship of $\mathbf{N}$ - and $\mathbf{P} / \mathbf{Q}$-type $I_{\mathbf{C a}}$}

The hyperpolarized shift in the voltage dependence of relief from inhibition could be attributable to shifts in the gating of the $\mathrm{P} / \mathrm{Q}$-type current relative to the N-type current. This was investigated by comparing the current-voltage relationship for the two 

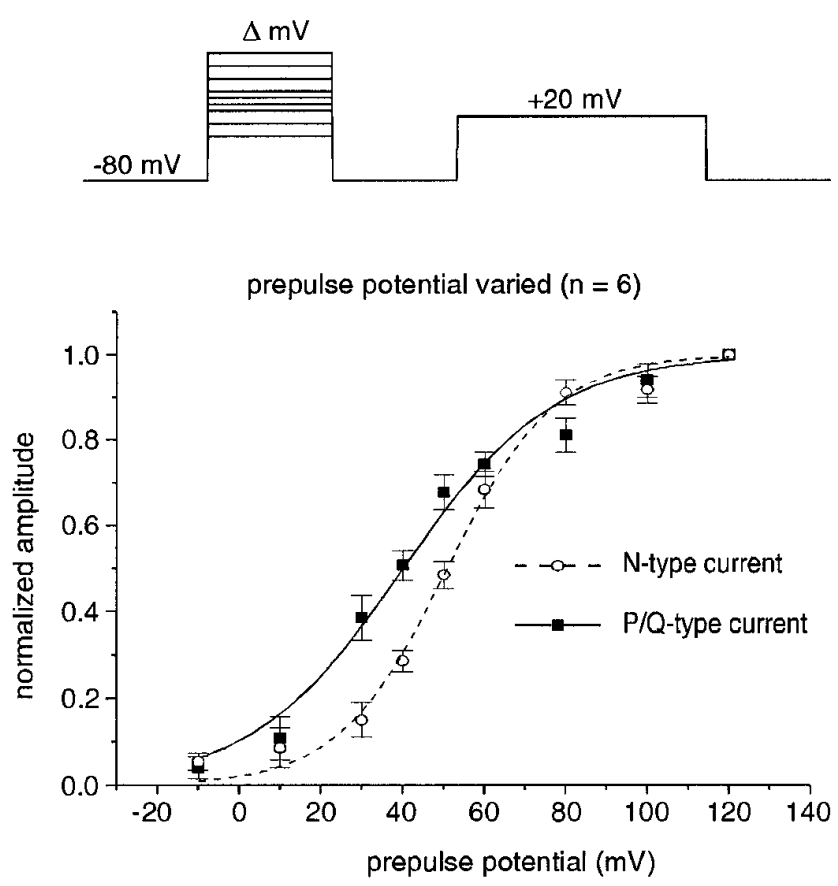

Figure 6. Comparison of the voltage dependence of the relief from inhibition for $\mathrm{N}$ - and $\mathrm{P} / \mathrm{Q}$-type channels. The voltage protocol used is shown at the top. The holding potential was $-80 \mathrm{mV}$, and the test pulse was to $+20 \mathrm{mV}$ for $20 \mathrm{msec}$. The duration of the prepulse and interpulse was not varied, and both were $10 \mathrm{msec}$. The potential of the prepulse was varied from -10 to $+120 \mathrm{mV}$. The patch pipette contained GTP- $\gamma$-S (70 $\mu \mathrm{M})$ to elicit the inhibition. Voltage protocols were repeated before and after application of $\omega$-Cgtx GVIA $(1 \mu \mathrm{M})$ to isolate the $N$-type and $P / Q$ type currents. The graph plots data from six cells in which the increase in amplitude produced by each of the prepulses was normalized to the increase produced by the most positive prepulse $(+120 \mathrm{mV})$. The data were plotted against prepulse potential and fit with a sigmoidal curve.

current types, using ramp depolarizations from -80 to $+100 \mathrm{mV}$. These experiments were performed in choline Cl-based recording solution to minimize the contribution of TTX-resistant sodium channels if present. Ramps were performed before and after application of either $\omega$-Cgtx GVIA (to isolate the N-type current) or $\omega$-Aga IVA (to isolate the P/Q-type current). Application of $\omega$-Cgtx GVIA reduced the amplitude of $I_{\mathrm{Ca}}$ and produced a small but statistically significant leftward shift in the $I / V$ relationship relative to control (Fig. $7 A$ ). Application of $\omega$-Aga IVA also reduced the amplitude and shifted the $I / V$ curve by a similar amount but in the opposite direction (Fig. $7 B$ ), indicating that the shift was due to genuine differences in the properties of the $\mathrm{N}$ and P/Q-type currents. The mean data revealed a statistically significant hyperpolarized shift $(7-10 \mathrm{mV})$ in the peak of the $I / V$ curve for the $\mathrm{P} / \mathrm{Q}$-type current relative to the $\mathrm{N}$-type current (Table 1).

The percentage inhibition produced by ATP was examined by using $\operatorname{ramp} I / V=$ curves $(n=5)$, and it was found that there was no significant difference in the extent of the inhibition over a 30 $\mathrm{mV}$ voltage range spanning the peak for both current types $(+10$ to $+30 \mathrm{mV}$ for the P/Q-type $I_{\mathrm{Ca}} ;+20$ to $+40 \mathrm{mV}$ for the N-type $\left.I_{\mathrm{Ca}}\right)$. The inhibition was proportionally less for both current types at potentials both negative and positive to those stated above. Hence, the differential inhibition reported in this paper using step depolarizations (to +20 or $+30 \mathrm{mV}$ ) were not artifacts generated by the shift in gating properties for the two current types.

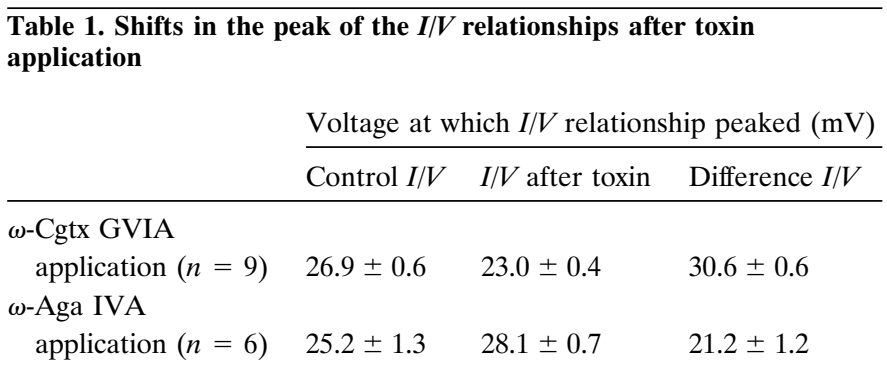

The voltage at which the $I / V$ relationship peaked was measured before toxin application (control $I / V)$ and after application of either $1 \mu \mathrm{M} \omega$-Cgtx GVIA to block $\mathrm{N}$-type $I_{\mathrm{Ca}}$ or $400 \mathrm{nM} \omega$-Aga IVA to block P/Q-type $I_{\mathrm{Ca}}(I / V$ after toxin). Subtraction of $I / V$ curves obtained after toxin application from those obtained before toxin application yielded difference $I / V$ curves representing the pure $\mathrm{N}$-type or $\mathrm{P} / \mathrm{Q}$-type currents. The shifts after application of either toxin relative to control were statistically significant $(p<0.01)$, as were the shifts between the $I / V$ after toxin and the difference $I / V(p<0.0003)$.

\section{DISCUSSION}

\section{$\mathrm{N}$-type channels are preferentially targeted by ATP}

Cultured bovine adrenal chromaffin cells provide a good model in which to compare the inhibition of $\mathrm{N}$ - and $\mathrm{P} / \mathrm{Q}$-type $I_{\mathrm{Ca}}$ because they are voltage-clamped readily, express the currents in an approximately 1:1 ratio, and we previously have characterized the inhibition produced by ATP (Currie and Fox, 1996). This paper clearly demonstrates that the $\mathrm{N}$-type $I_{\mathrm{Ca}}$ was inhibited to a greater extent than the P/Q-type $I_{\mathrm{Ca}}$. A supramaximal dose of ATP (100 $\mu \mathrm{M} ; \mathrm{EC}_{50}=0.5 \mu \mathrm{M}$ ) was used to ensure full activation of the receptors before and after application of either $\omega$-Cgtx GVIA or $\omega$-AGA IVA to isolate the two currents. This ruled out the possibility that the difference was due to cell variability or the level of G-protein activation and was confirmed by using GTP- $\gamma$-S to maximally stimulate the inhibition in an irreversible manner.

A small component of current in the chromaffin cells was insensitive to either $\omega$-Cgtx GVIA or $\omega$-Aga IVA. Although not thoroughly investigated, ATP inhibited this current in some cells (Currie and Fox, unpublished data). To ensure that the toxininsensitive current did not account for the differential inhibition of the N- and P/Q-type $I_{\mathrm{Ca}}$, we used both $\omega$-Cgtx GVIA and $\omega$-Aga IVA to isolate the currents. Thus, in some cases the residual toxin-insensitive current was included in the N-type $I_{\mathrm{Ca}}$, and in others it was included in the P/Q-type $I_{\mathrm{Ca}}$, but this had little effect on the data because in all cases the residual current was extremely small.

Using conditioning prepulses, we classified the inhibition as either voltage-sensitive (that component relieved by a prepulse) or voltage-insensitive (that component present after a prepulse). This classification is purely functional, because it is by no means clear whether the two components represent different signaling pathways or whether there is only partial reversal of a single inhibitory mechanism. Nevertheless, it was striking that the voltage-insensitive component of the inhibition accounted for the same percentage reduction of the $\mathrm{N}$ - and $\mathrm{P} / \mathrm{Q}$-type currents $(\approx$ $20 \%$ ) and that the difference in the inhibition was accounted for by the voltage-sensitive component $(\approx 45 \% \mathrm{Vs} \approx 18 \%)$.

\section{Properties of the voltage-sensitive inhibition}

Both the $\mathrm{N}$ - and P/Q-type currents exhibited the typical characteristics of this type of inhibitory modulation, including slowed activation kinetics and partial reversal by prepulses to very depolarized potentials. These characteristics have been incorporated into models (Bean, 1989; Elmslie et al., 1990; Boland and Bean, 
A

\section{$\omega$-conotoxin GVIA block}

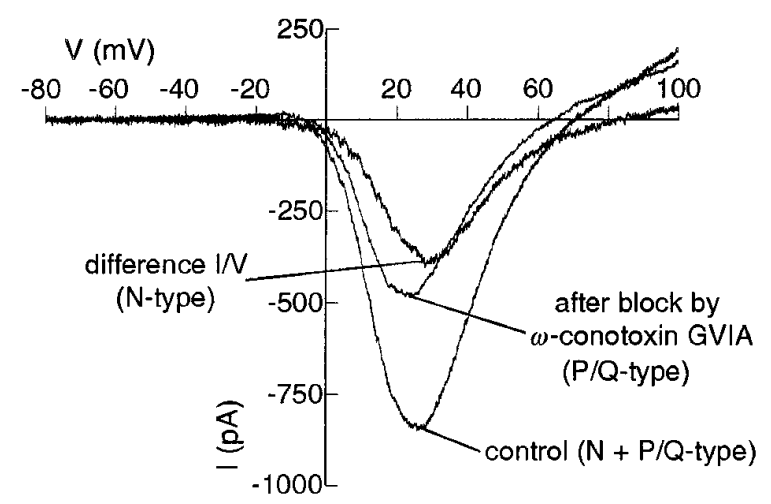

B

\section{$\omega$-Agatoxin IVA block}

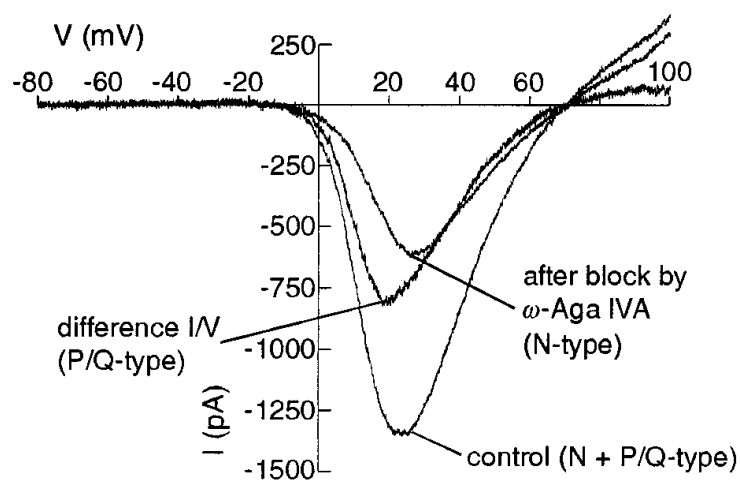

Figure 7. Voltage dependence of $\mathrm{N}$ - and $\mathrm{P} / \mathrm{Q}$-type calcium current $I / V$ curves. $A$, Three $I / V$ curves are superimposed. The first (control) was obtained before toxin application and so is composed of both $\mathrm{N}$ - and P/Q-type $I_{\mathrm{Ca}}$. The second was obtained after block by $\omega$-Cgtx GVIA $(1 \mu \mathrm{M})$ and thus represents mainly the $\mathrm{P} / \mathrm{Q}$-type current (along with the small toxin-insensitive component). Note that in addition to a reduction in amplitude the $\omega$-Cgtx GVIA shifted the $I / V$ curve to the left. The third curve was obtained by subtracting the curve obtained after $\omega$-Cgtx GVIA from that obtained before $\omega$-Cgtx GVIA. This difference $I / V$ represents the pure N-type current and is shifted to the right relative to control. Note that the shift in reversal potential was apparent only in some cells and was attributable, at least in part, to a small residual current present in some cells after leak subtraction. B, In this set of experiments $\omega$-Agatoxin IVA (400 nM) was used to block and isolate $\mathrm{P} / \mathrm{Q}$-type $I_{\mathrm{Ca}}$. After block with $\omega$-Aga IVA, the $I / V$ curve shifted to the right, and the difference $I / V$ shifted to the left relative to control. Both manipulations reveal that the $P / Q$-type $I / V$ curve shifted by $\sim 7 \mathrm{mV}$ to the left relative to the $\mathrm{N}$-type $I / V$ curve.

1993; Golard and Siegelbaum, 1993) in which the channels exhibit two functional gating states, one from which they readily open on depolarization (willing) and one from which they open slowly (reluctant). Activation of the inhibitory pathway (perhaps binding of the G-protein $\beta \gamma$ subunit to the channel) shifts a proportion of the channels into the reluctant state, but strong depolarizations can still open these channels and overcome the inhibition, possibly by promoting the dissociation of the G-protein subunit or subunits from the channel (but see Kasai, 1992).

Despite the 2.5-fold difference in the magnitude of the voltagesensitive inhibition, there were only small differences in the time course for relief from inhibition or for reinhibition of the two channel types. There was a significant shift in the voltage dependence of the relief from inhibition (Fig. 6), but this may be accounted for by the similar shift in the current-voltage relationships of the two channels ( $-10 \mathrm{mV}$ for the $\mathrm{P} / \mathrm{Q}$ - relative to the $\mathrm{N}$-type). In this study the activation in the presence of inhibitor could not be well fit even with multiple exponentials and was complicated further by somewhat different $\mathrm{Ca}^{2+}$-dependent inactivation kinetics of the $\mathrm{N}$ - and $\mathrm{P} / \mathrm{Q}$ type currents. This prevented a quantitative comparison, but qualitatively the slowing was similar for the $\mathrm{N}$ - and P/Q-type $I_{\mathrm{Ca}}$. Thus, all of our data point to there being little difference in the voltagesensitive inhibition of the two channel types in terms of the kinetics or voltage dependence.

\section{What accounts for the differential inhibition of the two channel types?}

For the purposes of this discussion we will assume that the voltage-sensitive inhibition is produced by direct interaction of the activated G-protein subunit or subunits with the calcium channel, as represented by the simple binding scheme below:

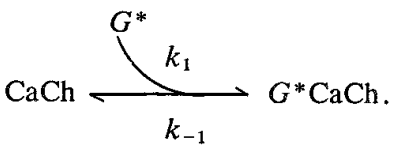

In Equation 1 above, $\mathrm{CaCh}$ represents either the $\mathrm{N}$-type or P/Q-type calcium channel, $G^{*}$ the activated G-protein, and $k_{1}$ and $k_{-1}$ are the forward and back rate constants, respectively. The interaction site or sites seem to be on the $\alpha_{1}$ subunit of the calcium channel, because channels expressed in Xenopus oocytes by either $\alpha_{1 \mathrm{~A}}$ or $\alpha_{1 \mathrm{~B}}$ subunits alone are susceptible to G-protein-mediated inhibition (Roche et al., 1995; Bourinet et al., 1996). Binding sites for G-protein $\beta \gamma$ subunits recently have been identified in the I-II linker of the $\alpha_{1 \mathrm{~A}}$ and $\alpha_{1 \mathrm{~B}}$ subunits (De Waard et al., 1997; Zamponi et al., 1997), but see Zhang et al. (1996) for a report in which sites in both domain I and the $\mathrm{C}$ terminus of the $\alpha_{1}$ subunit are involved in G-protein modulation. The calcium channel $\beta$-subunit also plays a role, because it clearly "antagonizes" the inhibition in both native (Campbell et al., 1995) and recombinant channels (Bourinet et al., 1996).

Assuming a binding model such as (Eq. 1), the fractional occupancy of the channels by G-proteins can be written as:

$$
\frac{k_{1}\left[G^{*}\right]}{k_{1}\left[G^{*}\right]+k_{-1}} \text {. }
$$

The time constant for binding of the G-protein to the channel, for instance during reblock of the channels after a prepulse, is:

$$
\tau=\frac{1}{\left(k_{-1}+k_{1}\left[G^{*}\right]\right)} .
$$

Recently Tsien and colleagues compared the inhibition of cloned $\alpha_{1 \mathrm{~A}}$ and $\alpha_{1 \mathrm{~B}}$ channels expressed in Xenopus oocytes (Zhang et al., 1996). They suggested that variations in the off-rate $\left(k_{-1}\right)$ of the G-protein from the channel explain the differences in the extent of inhibition (fractional occupancy, Eq. 2) and reinhibition rate (Eq. 3 ) that they observed for the two channel types. Our data obtained in native channels from chromaffin cells show that the kinetics of relief from inhibition and reinhibition between the two channel types are very similar, suggesting that the off-rate remains unchanged. If there is an increase in the G-protein off-rate $\left(k_{-1}\right)$ for 
the $\mathrm{P} / \mathrm{Q}$-type channels relative to $\mathrm{N}$-type channels, it suggests that the local concentration of activated G-proteins near P/Q-type channels is lower, such that the kinetics for the two channel types (Eq. 3) remain similar. Alternatively, the difference in reinhibition rate observed between our study and that of Zhang et al. (1996) may be attributable to the fact that the channels expressed in the Xenopus oocyte system are not identical to those in chromaffin cells. These differences may reside in the $\alpha_{1}$ subunit or in accessory subunits. A preliminary report showed that the extent of inhibition of currents produced by expression of $\alpha_{1 \mathrm{~A}}$ or $\alpha_{1 \mathrm{~B}}$ alone was similar but that coexpression of a $\beta_{3}$-subunit led to a greater reduction in the inhibition of $\alpha_{1 \mathrm{~A}}$, as compared with $\alpha_{1 \mathrm{~B}}$ (Roche and Treistman, 1996). This suggests that the influence of the calcium channel $\beta$-subunit is critical in leading to the differential inhibition of the two channel types.

Another explanation of our data is that, rather than the affinity of the G-protein/calcium channel interaction, it is the efficacy with which the bound G-protein exerts its actions that is different for the two channel types (off-rates and G-protein concentrations are similar for the two channel types). However, this explanation is not consistent with the data of Zhang et al. (1996).

\section{$\mathrm{N}$ - and $\mathrm{P} / \mathrm{Q}$-type calcium channels as targets for regulation of neurotransmission}

$\mathrm{N}$-type calcium channels are targets of at least five inhibitory pathways (Hille, 1994), and it now seems that P/Q-type channels are inhibited in a similar manner. It remains unclear whether the voltage-dependent relief from inhibition identifies two distinct pathways or whether there is partial relief of a single pathway. Phosphorylation may mediate the voltage-insensitive inhibition in at least some cell types (Diversé-Pierluissi et al., 1995). Functionally, the voltage-sensitive inhibition is greater for the $\mathrm{N}$-type channels and also may provide a more "dynamic" aspect to the inhibition. This would be achieved if there were relief from inhibition during trains of action potentials. However, use of short depolarizing steps to mimic action potentials suggests that for $\mathrm{N}$-type channels this may be confined to cells capable of firing at very high rates (Penington et al., 1991; Williams et al., 1997). Relief of $\mathrm{P} / \mathrm{Q}$-type channel inhibition by action potentials may depend on the duration of the action potential waveform (Brody et al., 1997).

The nonlinear relationship between intracellular calcium levels and secretion (Heinemann et al., 1994) means that even small changes in calcium influx could have profound effects on transmitter release. Ultimately, the regulation of neurotransmitter release will be due to the summation of many subtle inputs, including the inhibition of $I_{\mathrm{Ca}}$ investigated in this paper. There is also evidence to suggest that P/Q-type channels may be potentiated selectively in some systems (Mogul et al., 1993; Huang et al., 1996). Hence, one might envisage a situation whereby the relative proportion of $\mathrm{N}$ - and $\mathrm{P} / \mathrm{Q}$-type channels at synapses would be regulated precisely. Synapses in which $\mathrm{P} / \mathrm{Q}$-type channels dominate would be inhibited less and so would operate over a smaller range (between uninhibited and maximally inhibited states) than synapses in which $\mathrm{N}$-type channels dominate, thus providing a fine tuning of the regulation of release.

\section{REFERENCES}

Artalejo CR, Ariano MA, Perlman RA, Fox AP (1990) Activation of facilitation calcium channels in chromaffin cells by $D_{1}$ dopamine receptors through a cAMP/protein kinase A-dependent mechanism. Nature 348:239-242.

Artalejo CR, Dahmer MK, Perlman RA, Fox AP (1991) Two type of
$\mathrm{Ca}^{2+}$ currents are found in bovine chromaffin cells: facilitation is due to recruitment of one type. J Physiol (Lond) 432:681-707.

Artalejo CR, Perlman RA, Fox AP (1992a) $\omega$-Conotoxin GVIA blocks a $\mathrm{Ca}^{2+}$ current in bovine chromaffin cells that is not of the "classic" N-type. Neuron 8:85-95.

Artalejo CR, Perlman RA, Fox AP (1992b) Voltage-dependent phosphorylation may recruit $\mathrm{Ca}^{2+}$ current facilitation in chromaffin cells. Nature 358:63-66.

Bayliss DA, Umemiya M, Berger AJ (1995) Inhibition of N- and P-type calcium currents and the after-hyperpolarization in rat motoneurones by serotonin. J Physiol (Lond) 485:635-647.

Bean BP (1989) Neurotransmitter inhibition of neuronal calcium currents by changes in channel voltage dependence. Nature 340:153-156.

Boland LM, Bean BP (1993) Modulation of N-type calcium channels in bullfrog sympathetic neurons by luteinizing hormone-releasing hormone: kinetics and voltage dependence. J Neurosci 13:516-533.

Bourinet E, Soong T, Stea A, Snutch TP (1996) Determinants of the G-protein-dependent opioid modulation of neuronal calcium channels. Proc Natl Acad Sci USA 93:1486-1491.

Brody DL, Patil PG, Mulle JG, Snutch TP, Yue DT (1997) Bursts of action potential waveforms relieve G-protein inhibition of recombinant P/Q-type $\mathrm{Ca}^{2+}$ channels in HEK293 cells. J Physiol (Lond) 499:637-644.

Campbell V, Berrow NS, Fitzgerald EM, Brickley K, Dolphin AC (1995) Inhibition of the interaction of G-protein $G_{o}$ with calcium channels by the calcium channel $\beta$-subunit in rat neurones. J Physiol (Lond) 485:365-372.

Currie KPM, Fox AP (1996) ATP serves as a negative feedback inhibitor of voltage-gated $\mathrm{Ca}^{2+}$ channel currents in cultured bovine adrenal chromaffin cells. Neuron 16:1027-1036.

De Waard M, Liu H, Walker D, Scott VES, Gurnett CA, Campbell KP (1997) Direct binding of G-protein $\beta \gamma$ complex to voltage-dependent calcium channels. Nature 385:446-450.

Diversé-Pierluissi M, Goldsmith PK, Dunlap K (1995) Transmittermediated inhibition of N-type calcium channels in sensory neurons involves multiple GTP-binding proteins and subunits. Neuron 14:191-200.

Dolphin AC (1995) Voltage-dependent calcium channels and their modulation by neurotransmitters and G-proteins. Exp Physiol 80:1-36.

Dubel SJ, Starr TV, Hell J, Ahlijanian MK, Enyeart JJ, Catterall WA, Snutch TP (1992) Molecular cloning of the $\alpha-1$ subunit of an $\omega$-conotoxin-sensitive calcium channel. Proc Natl Acad Sci USA 89:5058-5062.

Elmslie KS, Zhou W, Jones SW (1990) LHRH and GTP- $\gamma-S$ modify calcium current activation in bullfrog sympathetic neurons. Neuron 5:75-80.

Fenwick EM, Marty A, Neher E (1982) Sodium and calcium channels in bovine chromaffin cells. J Physiol (Lond) 331:599-635.

Golard A, Siegelbaum SA (1993) Kinetic basis for the voltage-dependent inhibition of N-type calcium current by somatostatin and norepinephrine in chick sympathetic neurons. J Neurosci 13:3884-3894.

Hamill OP, Marty A, Neher E, Sakmann B, Sigworth FJ (1981) Improved patch-clamp techniques for high resolution current recording from cells and cell free membrane patches. Pflügers Arch 391:85-100.

Heinemann C, Chow RH, Neher E, Zucker RS (1994) Kinetics of the secretory response in bovine chromaffin cells following flash photolysis of caged $\mathrm{Ca}^{2+}$. Biophys J 67:2546-2557.

Herlitze S, Garcia DE, Mackie K, Hille B, Scheuer T, Catterall WA (1996) Modulation of $\mathrm{Ca}^{2+}$ channels by G-protein $\beta \gamma$ subunits. Nature 380:258-262.

Hille B (1992) G-protein-coupled mechanisms and nervous signaling. Neuron 9:187-195.

Hille B (1994) Modulation of ion channel function by G-protein-coupled receptors. Trends Neurosci 17:531-536.

Huang C-C, Hsu K-S, Gean P-W (1996) Isoproterenol potentiates synaptic transmission primarily by enhancing presynaptic calcium influx via $\mathrm{P}$ - and/or Q-type calcium channels in the rat amygdala. J Neurosci 16:1026-1033.

Ikeda SR (1996) Voltage-dependent modulation of N-type calcium channels by G-protein $\beta \gamma$ subunits. Nature 380:255-258.

Kasai H (1992) Voltage- and time-dependent inhibition of neuronal calcium channels by a GTP-binding protein in a mammalian cell line. J Physiol (Lond) 448:189-200.

Liu H, De Waard M, Scott VES, Gurnett CA, Lennon VA, Campbell KP 
(1996) Identification of three subunits of the high affinity $\omega$-conotoxin MVIIC-sensitive $\mathrm{Ca}^{2+}$ channel. J Biol Chem 271:13804-13810.

Llinás R, Sugimori M, Lin JW, Cherksey B (1989) Blocking and isolation of a calcium channel from neurons in mammals and cephalopods utilizing a toxin fraction (FTX) from funnel-web spider poison. Proc Natl Acad Sci USA 86:1689-1693.

Luebke JI, Dunlap K, Turner TJ (1993) Multiple calcium channel types control glutamatergic synaptic transmission in the hippocampus. Neuron 11:895-902.

McCleskey EW, Fox AP, Feldman D, Cruz LJ, Olivera BM, Tsien RW, Yoshikami D (1987) $\omega$-Conotoxin: direct and persistent blockade of specific types of calcium channels in neurons but not muscle. Proc Natl Acad Sci USA 84:4327-4331.

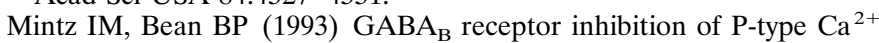
channels in central neurons. Neuron 10:889-898.

Mintz IM, Adams ME, Bean BP (1992) P-type calcium channels in rat central and peripheral neurons. Neuron 9:85-95.

Mogul DJ, Adams ME, Fox AP (1993) Differential activation of adenosine receptors decreases N-type but potentiates P-type $\mathrm{Ca}^{2+}$ current in hippocampal CA3 neurons. Neuron 10:327-334.

Penington NJ, Kelly JS, Fox AP (1991) A study of the mechanism of $\mathrm{Ca}^{2+}$ current inhibition produced by serotonin in rat dorsal raphe neurons. J Neurosci 11:3594-3609.

Plummer MR, Logothetis DE, Hess P (1989) Elementary properties and pharmacological sensitivities of calcium channels in mammalian peripheral neurons. Neuron 2:1453-1463.

Randall AD, Tsien RW (1995) Pharmacological dissection of multiple types of $\mathrm{Ca}^{2+}$ channel current in rat cerebellar granule neurons. J Neurosci 15:2995-3012.

Regehr WG, Mintz IM (1994) Participation of multiple calcium channel types in transmission at a single climbing fibre to Purkinje cell synapses. Neuron 12:605-613.

Roche JP, Treistman SN (1996) Characterization of G-protein-mediated inhibition of $\alpha_{1 \mathrm{~A}}$ and $\alpha_{1 \mathrm{~B}} \mathrm{Ca}^{2+}$ channels. Soc Neurosci Abstr 22:71.

Roche JP, Anantharam V, Treistman SN (1995) Abolition of G-protein inhibition of $\alpha_{1 \mathrm{~A}}$ and $\alpha_{1 \mathrm{~B}}$ calcium channels by co-expression of the $\beta_{3}$ subunit. FEBS Lett 371:43-46.

Stea A, Tomlinson WJ, Soong TW, Bourinet E, Dubel SJ, Vincent SR, Snutch TP (1994) Localization and functional properties of a rat brain $\alpha_{1 \mathrm{~A}}$ calcium channel reflects similarities to neuronal Q- and P-type channels. Proc Natl Acad Sci USA 91:10576-10580.

Takahashi T, Momiyama A (1993) Different types of calcium channels mediate central synaptic transmission. Nature 366:156-158.

Waterman SA (1996) Multiple subtypes of voltage-gated calcium channel mediate transmitter release from parasympathetic neurons in the mouse bladder. J Neurosci 16:4155-4161.

Wheeler DB, Randall AD, Tsien RW (1994) Roles of N-type and Q-type $\mathrm{Ca}^{2+}$ channels in supporting hippocampal synaptic transmission. Science 264:107-111.

Williams ME, Brust PF, Feldman DH, Patthi S, Simerson S, Maroufi A, McCue AF, Velicelebi G, Ellis SB, Harpold MM (1992) Structure and functional expression of an $\omega$-conotoxin-sensitive human $\mathrm{N}$-type calcium channel. Science 257:389-395.

Williams S, Serafin M, Mühlethaler M, Bernheim L (1997) Facilitation of $\mathrm{N}$-type calcium current is dependent on the frequency of action potential-like depolarizations in dissociated cholinergic basal forebrain neurons of the guinea pig. J Neurosci 17:1625-1632.

Wright CE, Angus JA (1996) Effects of N-, P-, and Q-type neuronal calcium channel antagonists on mammalian peripheral neurotransmission. Br J Pharmacol 119:49-56.

Zamponi GW, Bourinet E, Nelson D, Nargeot J, Snutch TP (1997) Crosstalk between G-proteins and protein kinase $\mathrm{C}$ mediated by the calcium channel $\alpha_{1}$ subunit. Nature 385:442-446.

Zhang J-F, Randall AD, Ellinor PT, Horne WA, Sather WA, Tanabe T, Schwarz TL, Tsien RW (1993) Distinctive pharmacology and kinetics of cloned neuronal $\mathrm{Ca}^{2+}$ channels and their possible counterparts in mammalian CNS neurons. Neuropharmacology 32:1075-1088.

Zhang J-F, Ellinor PT, Aldrich RW, Tsien RW (1996) Multiple structural elements in voltage-dependent $\mathrm{Ca}^{2+}$ channels support their inhibition by G-proteins. Neuron 17:991-1003. 